\title{
SPORMETRE
}

The Journal of Physical Education and Sport Sciences Beden Eğitimi ve Spor Bilimleri Dergisi

DOI: $10.33689 /$ spormetre.598251

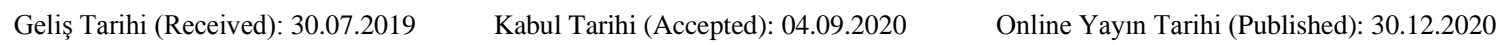

\section{ADÖLESAN AMATÖR FUTBOLCULARIN BESLENME DURUMUNUN DEĞERLENDİRILMESI*}

\author{
Hilal HIZLI GÜLDEMİR ${ }^{* *} \mathbb{D}$, Emre BAYRAKTAROĞLU ${ }^{2}$ (D) \\ ${ }^{1}$ Kütahya Sağlık Bilimleri Üniversitesi, Sağlık Bilimleri Fakültesi, Beslenme ve Diyetetik Bölümü, KÜTAHYA \\ ${ }^{2}$ İstanbul Medipol Üniversitesi, Sağlık Bilimleri Yüksekokulu, Beslenme ve Diyetetik Bölümü, İSTANBUL
}

\begin{abstract}
Öz: Bu çalışma; amatör olarak futbol oynayan, 14-18 yaş arası erkek adölesanların beslenme durumlarını değerlendirmek amacıyla yapılmıştır. Çalışmaya çeşitli futbol kulüplerinin alt yapı takımlarında oynayan 113 adölesan dahil edilmiştir. Bireylere ait demografik bilgiler ile beslenme alışkanlıkları, yüz yüze görüşme yöntemiyle uygulanan anket formu aracıllğıyla elde edilmiştir. Ağırlık ve boy ölçümleri yapılmış, BKİ ve Z skoru hesaplanmıştır. Geriye dönük bir günlük besin tüketim kaydı alınarak, enerji ve besin öğesi alımları BeBiS programı ile hesaplanmış ve veriler istatistiksel olarak değerlendirilmiştir. Bireylerin ortalama yaşı $15,7 \pm 1,3$ yıl ve BKI'si $20,56 \pm 1,87 \mathrm{~kg} / \mathrm{m}^{2}$ 'dir. Antrenman öncesinde adölesanların \%90,3'ü beslenmesine, $\% 93,8$ 'i sıv1 alımına dikkat ettiğini bildirmesine rağmen, $\% 39,8^{\prime} \mathrm{i}$ antrenman öncesi $0,5 \mathrm{~L}$ veya daha az miktarda sıvı tüketmektedir. Adölesanların \%53,1’i ara öğün yapmamakta, \%24,8'i ise kahvaltıyı atlamaktadır. Günlük enerji alımları ortalama 2081,94 \pm 668,51 kkal olup, gereksinimlerinin sadece \%63,1'ini karşılamaktadır. Enerjinin günlük ortalama $\% 44,5$ 'inin karbonhidrattan, $\% 16,2$ 'sinin proteinden sağlandığı; lifin yeterli $(\% 101,00)$; kalsiyum, potasyum ve çinkonun ise yetersiz $(\% 77,17 ; \% 52,13 ; \% 83,41)$ tüketildiği belirlenmiştir. Adölesanların BKİ'lerinin normal olduğu, ancak bazı önemli besin öğeleri yönünden yetersiz beslendikleri sonucuna varılmıştır. Bu yaş grubundaki sporcuların hem büyüme gelişme hem de yaptıkları spor dalına uygun beslenmeleri için erken yaşta sağlıklı beslenme bilinci geliştirilmesi, ilerleyen yaşlardaki yaralanma riskinin azaltılması ve spor performansının artırılması için önemlidir.
\end{abstract}

Anahtar Kelimeler: Adölesan, beslenme durumu, futbolcu, sıvı tüketimi

\section{EVALUATION OF THE NUTRITION OF ADOLESCENT AMATEUR FOOTBALL PLAYERS}

\begin{abstract}
This study was conducted to evaluate the nutritional status of male adolescents aged 14-18 years playing football as amateurs. A hundred and thirteen adolescents who played in the youth setups of various football clubs were included in the study. The demographic information and eating habits of the individuals were obtained through a questionnaire applied by face to face interview method. Weight and height measurements were taken and BMI and Z scores were calculated. A retrospective daily food consumption record was obtained, and energy and nutrient consumption were calculated with the BeBiS program and the data were evaluated statistically. The mean age of the subjects was $15.7 \pm 1.3$ years and their BMI was $20.56 \pm 1.87 \mathrm{~kg} /$ $\mathrm{m}^{2}$. Although $90.3 \%$ of the adolescents reported that they were paying attention to nutrition and $93.8 \%$ paying attention to fluid intake before the training, $39.8 \%$ consumed $0.5 \mathrm{~L}$ or less before the training. $53.1 \%$ of adolescents do not eat snacks and $24.8 \%$ skip breakfast. The average daily energy intake is $2081.94 \pm 668.51$ kcal and only $63.1 \%$ of its requirements are met. On average $44.5 \%$ of the daily carbohydrate energy, $16.2 \%$ of the protein is provided; fiber intake is sufficient $(101.00 \%)$; it was determined that the levels of calcium, potassium and zinc were consumed inadequate $(77.17 \% ; 52.13 \% ; 83.41 \%)$. It was concluded that the BMI of adolescents was normal but they were undernourished in terms of some important nutrients. Developing healthy nutrition awareness at an early age is important for athletes in this age group for both growth and development, as well as for proper nutrition for the sport they play. It will also reduce the risk of injury at later ages and to increase sports performance.
\end{abstract}

Key Words: Adolescent, fluid consumption, football player, nutrition

*Bu çalışma 23-26 Kasım 2017 tarihleri arasında İstanbul'da düzenlenen 2. İstanbul Ulusal Beslenme ve Diyetetik
Kongresi'nde poster sunum olarak sunulmuştur.




\section{GİRIŞ}

Adölesan dönem; fiziksel, psikolojik ve sosyal yönden büyüme, gelişme ve olgunlaşma ile karakterize ve çocukluktan yetişkinliğe geçişin başladığı, bebeklik çağından sonraki ikinci hızlı gelişmenin olduğu bir dönemdir. Sürekli büyüme özelliği çocukları yetişkinlerden ayıran en önemli özelliklerden biridir ve fiziksel yüklenmelere verdikleri cevaplar yetişkinlerden farklıdır. Aktif bir adölesanın günlük ortalama enerji ve besin öğeleri gereksinimi 2300-3000 kkal arasında değişmekte, besin öğesi ve sıvı gereksinimi de artmaktadır. Aynı zamanda Dünya Sağlık Örgütü (DSÖ) bu dönemde günde en az $60 \mathrm{dk}$ orta ile yüksek şiddetli fiziksel aktivite yapılmasını önermektedir (Diker ve Müniroğlu, 2016; WHO, 2011).

Beslenme ve yoğun fiziksel aktivite arasında karşılıklı bir ilişki vardır, yoğun fiziksel aktivite beslenme gereksinimlerini etkilerken, beslenme de antrenmanların daha verimli hale gelmesini ve müsabaka esnasında optimum performansın arttırılmasını sağlar (Desbrow ve ark., 2014). Beslenme, tüm sporcuların yaşamlarının ayrılmaz bir parçasıdır; ancak adölesan sporcular için doğru beslenmenin önemi daha da büyüktür. Artan çocukluk ve adölesan çağ 1 obezitesi ile genelde gençlerin beslenmesinde büyük dikkat gösterilmekte; ancak adölesan sporcuların beslenme gereksinimlerine çok az odaklanılmaktadır. Adölesanlar yüksek yetersiz beslenme riski taşıyan bir gruptur. Bu grupta yetersiz beslenme; büyüme geriliği, fiziksel ve mental gelişimde azalma ve ilerleyen dönemde kronik hastalıklara yakalanma riskinde artış gibi sorunlara neden olabilmektedir (TOÇBİ, 2011). Adölesan sporcularda beslenme, yetişkin sporculardan daha da önemlidir; çünkü adölesanların beslenmesinde öncelik büyüme ve gelişmeyi sürdürmektir. Bu nedenle doğru büyüme, gelişme ve olgunlaşma için yeterli enerji ve besin öğelerine olan gereksinim fazladır (IOM, 2005; Smith ve Jeukendrup, 2013). Ayrıca adölesan dönem bireyin besin ile yaşam boyu ilişsisinin temellerinin oluştuğu, öte yandan da diyet, egzersiz ve beden imajı arasındaki bağlantının öneminin benimsendiği bir zamandır (Desbrow ve ark., 2014).

Futbol, dünyanın en popüler spor dallarından biri olup, futbolcuların başarıları ve verimlikleri birçok faktöre bağlıdır. Futbol, aerobik ve anaerobik enerji sistemlerinin bir arada kullanıldığı, nöromüsküler ve kardiyorespiratuar dayanıklılık ile koordinasyon gibi faktörlerin performansa etki ettiği bir spor dalıdır (Cicioglu ve ark. 2001; Uğraş ve Özkan, 2002). Bir takım oyunu olmasına rağmen bireysel beslenme ve hidrasyon durumu başarıyı önemli ölçüde etkilemektedir. Sporcunun sağlığını korumanın yanı sıra performansını artırmak ve yaralanmaları önlemek gibi hedefler bulunmaktadır. Voleybol oyuncusu adölesanların dahil edildiği bir çalışmada, sportif performansı etkileyen diğer tüm etmenlerin eşit tutulduğu durumda, beslenmenin başarıda belirleyici bir etmen olduğu saptanmıştır (Salıcı, Akkaya, Ertürk ve Orhan, 2019). Adölesan sporcularda bu dönemde artan enerji, besin öğesi ve sıv1 gereksinimlerini yeterli miktarda karşılayamadıkları durumda büyüme ve gelişme duraklamakta, yaralanma riski artmaktadır. Demirezen ve Çoşansu (2005) tarafından yapılan çalışmada ise adölesanların olumsuz beslenme alışkanlıkları açısından risk taşıdığı ve bu riskin erkek adölesanlarda daha yüksek olduğu saptanmıştır. Ülkemizde Akman, Tüzün ve Ünalan (2012) tarafından yapılan başka bir araştırmada, adölesanların yetersiz beslendiği belirlenmiştir. Çocuklarda yeterli gelişmenin belirlenmesi, yaşa uygun vücut ağırlığı ve boy uzunluğunun ve beslenme durumunun saptanması; yani büyümenin takibi ile mümkündür (TOÇBİ, 2011). Bu nedenle bu çalışmada, yetersiz beslenme yönünden risk altında olan adölesan futbolcuların beslenme durumunun değerlendirilmesi ve varsa eksiklerin belirlenip beslenme durumlarını daha iyi seviyeye getirmek için yapılacak çalışmalara yol göstermek amaçlanmıştır. 


\section{YÖNTEM}

Bu çalışma, Ocak-Nisan 2017 tarihleri arasında çeşitli futbol kulüplerinin alt yapı takımlarında oynayan 14-18 yaş arası 113 erkek adölesan ile yürütülmüştür. Çalışmaya katılacak adölesanlar randomize olarak seçilmiş ve gönüllülük esası uygulanmıştır, İstanbul Medipol Üniversitesi Girişimsel Olmayan Klinik Araştırmalar Etik Kurulu'ndan onay alınmıştır (Sayı: 10840098604.01.01-E.10068).

Araştırmada gerekli verilerin toplanması için önceden yapılandırılmış bir anket formu, yüz yüze görüşme tekniği ile uygulanmıştır. Çalışmaya katılmayı kabul eden bireylerden gönüllü onam formu ile onay alınmıştır. Anket demografik bilgiler, antropometrik ölçümleri, beslenme alışkanlıkları ve besin tüketim kaydını içeren 4 bölümden oluşmaktadır.

Vücut ağırlığı, hassasiyeti $\pm 0.1 \mathrm{~kg}$. olan elektronik baskül ile futbolcuların ayakları cihazın elektrotlarına temas eder şekilde, ince kıyafetlerle ve mesane boş iken yapılmıştır. Boy uzunlukları ise hassasiyeti $\pm 1 \mathrm{~mm}$ olan Holtain marka stadiometre ile ayaklar yan yana ve baş Frankfurt düzlemde iken ayakkabısız olarak ölçülmüştür. Beden Kütle İndeksi (BKİ), vücut ağırlığı boy uzunluğunun metre cinsinden karesine bölünerek hesaplanmıştır. Boy uzunluğu ve BKI'lerinin değerlendirilmesinde Z skoru kullanılmış ve \pm 1 SD standart sapma aralığı normal kabul edilmiştir.

Adölesan futbolcuların günlük enerji ve besin ögeleri alımları "Besin Tüketim Formu" ile belirlenmiş, görüşme sırasında geriye dönük olarak son 24 saatte tükettikleri tüm besinler detaylı bir şekilde sorgulanarak kaydedilmiştir. Günlük enerji ve besin öğesi alımları, BeBiS 7.2 programı ile analiz edilmiştir. Yaş gruplarına göre gereksinimleri karşılama yüzdeleri Türkiye Beslenme Rehberi 2015 (TÜBER)'e göre hesaplanmıştır.

İstatistiksel analizlerde SPSS 22.0 programı kullanılmıştır. Elde edilen verilerin standart sapma (SS) ve medyanı bulunmuştur. Sürekli veriler; ortalama (Ort), standart sapma, ortanca, alt ve üst değerler ile tanımlanırken, kesikli veriler sıklık ve yüzde dağılımı şeklinde belirtilmiştir.

\section{BULGULAR}

Tablo 1. Adölesanlara ait demografik bilgiler

\begin{tabular}{lcc}
\hline Demografik Bilgiler & Ortalama & Standart Sapma \\
\hline Yaş (yıl) & 15,7 & 1,3 \\
Aktif spor süresi (yıl) & 7,4 & 2 \\
Haftada kaç kez antrenman & 5,11 & 0,6 \\
yapıldığı & & \\
\hline
\end{tabular}

Çalışmaya katılan sporcuların yaş ortalaması $15,7 \pm 1,3$ yıl olup, ortalama 7,4 \pm 2 yıldır aktif olarak spor ve haftada ortalama 5,11 $\pm 0,6 \mathrm{kez}$ antrenman yaptıkları belirlenmiştir (Tablo 1 ). 
Tablo 2. Adölesanların beslenme alışkanlıkları

\begin{tabular}{|c|c|c|}
\hline Beslenme Alışkanlıkları & $\mathbf{n}$ & $\%$ \\
\hline \multicolumn{3}{|l|}{ Daha önce diyetisyen ile çalışma } \\
\hline Evet & 8 & 7,1 \\
\hline Hayır & 105 & 92,9 \\
\hline \multicolumn{3}{|l|}{ Antrenman öncesinde beslenmeye dikkat etme } \\
\hline Evet & 102 & 90,3 \\
\hline Hayır & 11 & 9,7 \\
\hline \multicolumn{3}{|l|}{ Antrenman öncesi sıvı alımına dikkat etme } \\
\hline Evet & 106 & 93,8 \\
\hline Hayır & 7 & 6,2 \\
\hline \multicolumn{3}{|l|}{ Günlük toplam öğün sayısı } \\
\hline İki & 9 & 8 \\
\hline Üç & 65 & 57,5 \\
\hline Dört ve üzeri & 39 & 34,5 \\
\hline \multicolumn{3}{|l|}{ Atlanılan öğün } \\
\hline Kahvaltı & 28 & 24,8 \\
\hline Öğle & 21 & 18,6 \\
\hline Akşam & 4 & 3,5 \\
\hline Ara öğünler & 60 & 53,1 \\
\hline \multicolumn{3}{|l|}{ Öğün atlama nedeni } \\
\hline Yemeğe yeterli zaman ayıramamak & 73 & 64,6 \\
\hline İştahsızlık & 33 & 28,3 \\
\hline Vücut ağırlığını kontrol altına almak & 8 & 7,1 \\
\hline \multicolumn{3}{|l|}{ Günlük tüketilen toplam sıvı miktarı (L) } \\
\hline $1-2$ & 44 & 38,9 \\
\hline $2,2-4,8$ & 66 & 58,4 \\
\hline 5 ve üzeri & 3 & 2,7 \\
\hline \multicolumn{3}{|l|}{ Besin Desteği Kullanma } \\
\hline Evet (whey proteini, aminoasit desteği, multivitamin) & 14 & 12,3 \\
\hline Hayır & 99 & 86,8 \\
\hline
\end{tabular}

Sporcuların beslenme alışkanlıkları Tablo 2'de gösterilmiştir. Sadece \%7,1'i daha önce diyetisyen ile çalıştığını, \%90,3'ü antrenman öncesinde beslenmelerine, \%93,8'i ise antrenman öncesi sıvı alımına dikkat ettiğini beyan etmiştir. Sporcuların \%57,5'inin günde 3 öğün, \%34,5'inin günde 4 ve üzeri öğün beslendiği, en çok atlanılan öğünün ara öğünler olduğu $(\% 53,1)$, en s1k öğün atlama nedeninin ise zaman bulamamaktan kaynaklandığı $(\% 63,7)$ saptanmıştır. Günlük tüketilen toplam sıvı miktarının \%38,9'unun 1-2 L, \%58,4'ünün 2,2-4,8 L olduğu görülmüştür. Adölesanların sadece \%12,3'ünün besin desteği kullandığ belirlenmiştir. 
Tablo 3. Adölesanların antropometrik ölçümleri

\begin{tabular}{|c|c|c|c|c|c|c|c|}
\hline \multirow[t]{2}{*}{$\begin{array}{l}\text { Antropometrik } \\
\text { Ölçümler }\end{array}$} & \multirow[t]{2}{*}{$($ Ort \pm SS $)$} & \multicolumn{2}{|c|}{$\begin{array}{c}\text { Z Skoru (SD) } \\
-1 \text { ve altı }\end{array}$} & \multicolumn{2}{|c|}{$\begin{array}{c}\text { Z Skoru (SD) } \\
\text {-1 ve +1 }\end{array}$} & \multicolumn{2}{|c|}{$\begin{array}{l}\text { Z Skoru (SD) } \\
\text { +1 ve üstü }\end{array}$} \\
\hline & & $\mathrm{n}$ & $\%$ & $\mathrm{n}$ & $\%$ & $\mathrm{n}$ & $\%$ \\
\hline Vücut Ağırlığı (kg) & $64,36 \pm 8,86$ & - & - & - & - & - & - \\
\hline Boy Uzunluğu (cm) & $176,63 \pm 7,44$ & 3 & 2,66 & 63 & 55,75 & 47 & 41,59 \\
\hline BKİ (kg/m²) & $20,56 \pm 1,87$ & 5 & 4,43 & 104 & 92,03 & 4 & 3,54 \\
\hline
\end{tabular}

Tablo 3'te adölesanların antropometrik ölçümleri gösterilmiştir. Adölesanların ortalama boyu $176,63 \pm 7,44 \mathrm{~cm}$, vücut ağırlığ $64,36 \pm 8,86 \mathrm{~kg}$ ve BKI'lerinin $20,56 \pm 1,87 \mathrm{~kg} / \mathrm{m}^{2}$ olduğu belirlenmiştir. Boy uzunluğu ve BKI'leri +1 ve -1 SD arasında olanların oranının sırasıyla $\% 55,75$ ve \%92,03 olduğu bulunmuştur.

Tablo 4. Sporcuların günlük enerji ve besin ögesi alım miktarları

\begin{tabular}{|c|c|c|c|}
\hline Enerji ve Besin Öğeleri & $\begin{array}{l}\text { Ort } \pm S S \\
(n=113)\end{array}$ & Gereksinim* & $\begin{array}{c}\text { Karşılama Yüzdesi } \\
(\%)\end{array}$ \\
\hline Enerji (kkal) & $2081,94 \pm 668,51$ & $3393 * *$ & 61,36 \\
\hline Protein (g) & $81,11 \pm 31,94$ & 64,22 & 126,30 \\
\hline Protein (\%) & $16,26 \pm 7,05$ & - & - \\
\hline Karbonhidrat (g) & $228,11 \pm 84,45$ & 130 & 175,39 \\
\hline Karbonhidrat (\%) & $44,57 \pm 8,92$ & - & - \\
\hline Yağ (g) & $90,67 \pm 35,92$ & - & - \\
\hline Yağ (\%) & $39,35 \pm 8,25$ & - & - \\
\hline Kolesterol (mg) & $422,61 \pm 238,31$ & - & - \\
\hline Lif $(g)$ & $21,21 \pm 10,69$ & 21 & 101,00 \\
\hline A Vitamini (mcg) & $1099,24 \pm 561,46$ & 720 & 152,64 \\
\hline E Vitamini (mg) & $16,56 \pm 9,37$ & 13 & 127,39 \\
\hline Tiamin (mg) & $0,88 \pm 0,29$ & 1,2 & 73,00 \\
\hline Riboflavin (mg) & $1,56 \pm 0,59$ & 1,3 & 120,00 \\
\hline Niasin (mg) & $11,88 \pm 6,31$ & 13,95 & 85,16 \\
\hline Piridoksin (mg) & $1,41 \pm 0,54$ & 1,3 & 108,46 \\
\hline Folat (mcg) & $291,15 \pm 105,64$ & 318 & 91,56 \\
\hline Sodyum (g) & $4,03 \pm 2,07$ & 1,5 & 268,67 \\
\hline Potasyum (g) & $2,45 \pm 0,97$ & 4,7 & 52,13 \\
\hline Kalsiyum (mg) & $864,29 \pm 383,70$ & 1120 & 77,17 \\
\hline Magnezyum (mg) & $274,79 \pm 105,02$ & 310 & 88,64 \\
\hline Fosfor (mg) & $1309,65 \pm 438,19$ & 622 & 210,45 \\
\hline Demir (mg) & $11,44 \pm 4,01$ & 11 & 104,00 \\
\hline Çinko (mg) & $11,26 \pm 4,26$ & 13,5 & 83,41 \\
\hline
\end{tabular}

* Türkiye Beslenme Rehberi 2015'e göre günlük alınması gereken ortalama miktarın 14-18 yaş grubu için ortalama değerleri referans alınmıştır. ** Türkiye Beslenme Rehberi 2015'de yer alan ''Erkek çocuk ve adölesanlar için fiziksel aktivite düzeyine göre enerji gereksinimi ve enerji referans değerleri' 'içerisinden çok aktif bireyler için gereksinimler baz alınmıştır. 
Sporcuların günlük enerji ve besin ögesi alım miktarları ile gereksinimi karşılama yüzdeleri Tablo 4'te gösterilmiştir. Sporcuların; günlük ortalama enerji alımlarının 2081,94 $\pm 668,51$ kkal olduğu ve günlük enerji gereksinimlerinin \%61,36'sını karşıladıkları saptanmıştır. Enerjinin günlük ortalama \%44,5'inin karbonhidrattan, \%16,2'sinin proteinden ve \%39,3'ünün yağdan sağlandığı bulunmuştur. Sporcuların sodyum ve fosforu aşırı ( $\% 268,67$ ve $\% 210,45)$; potasyum ve kalsiyumu ise yetersiz $(\% 52,13$ ve \%\%77,17) tükettiği belirlenmiştir.

\section{TARTIŞMA VE SONUÇ}

$\mathrm{Bu}$ çalışma yaş ortalaması $15,7 \pm 1,3$ yıl olan 113 erkek adölesan amatör futbolcu ile yürütülmüştür.

Brezilya'da 2017 yılında yapılan bir çalışmada; adölesanlarda öğün atlamanın, meyve ve sebzelerden fakir, doymuş yağlardan, basit şekerlerden, sodyum ve enerji bakımından zengin diyet tüketimine neden olduğu, yine Brezilya'da aynı yıl yapılan bir başka çalışmada ise öğün sayısının azalmasının ve özelikle kahvaltı öğünün atlanmasının, enerji harcamasında artış görülmesine rağmen yüksek kan insülin seviyelerine neden olduğu bulunmuştur (Rodrigues ve arkadaşları 2017; Nas ve arkadaşları, 2017). Özkarabulut ve Yürek (2017) tarafından yapılan çalışmada, erkek adölesan sporcuların \%51,5'inin ara ögünleri, \%25,8'inin öğle, \%19,7'sinin kahvaltı, \%3'ünün akşam öğünlerini atladığı belirtilmiştir. Bu çalışmaya katılan sporcuların da benzer şekilde \%53,1'inin ara öğünleri atladığı, ara öğünlerden sonra en çok \%24,8 oranında kahvaltı öğününün atlandığı belirlenmiştir. Katılımcıların öğün atlama nedenleri arasında, bu çalışmaya benzer şekilde Özkarabulut ve Yürek'in (2017) yürüttüğü çalışmada zaman sıkıntısı ve iştahsızlık ön plana çıkmaktadır.

Erkek futbol oyuncularında yapılan bir araştırmada dehidrasyonun, zihinsel faktörleri etkileyebildiği ortaya konmuştur (Fortes, Nascimento-Júnior, Mortatti, Lima-Júnior ve Ferreira, 2018). Parlak ve arkadaşları (2008) tarafından yapılan bir araştırmaya katılan 15-18 yaş arası sporcuların 1 saat spor yaptıkları, günde \%18,6'sının 0,5 L'den az, \%39,4'ünün 1 ile 1,5 L arası, \%22,8'inin 1,5 ile 2,5 L aras1, \%19,2'sinin ise 2,5 L'den fazla sıv1 tükettiği bildirilirken, bu çalışmada günde toplam \%38.9'unun 1 ile $2 \mathrm{~L}$ arası, \%58,4'ünün 2 ile $4 \mathrm{~L}$ aras1 sıvı tükettikleri belirlenmiştir. Bu çalışmaya katılan adölesanların sıvı tüketim durumunun daha iyi olduğu söylenebilir.

Sporcularda besin desteği kullanımı gün geçtikçe artmakta ve besin desteğine başlama yaşı düşmektedir (Karakuş, 2014). Kaynağı belirli olmayan besin desteklerinin bilinçsizce kullanımı, adölesan sporcuların doping testlerinden pozitif sonuç almalarına neden olabilmektedir (Whitehouse ve Lawlis, 2017). Spor liselerinde yapılan bir çalışmaya katılanların \%24,5'i düzenli olarak besin desteği kullanırken, \% 75,5'i kullanmadığını belirtmiş ve kullanan kişilerin \%45,8'i kendi istekleri geri kalanları ise antrenörlerinin önerisi üzerine kullandıkları belirtilirken hiçbir katılımcı herhangi bir sağlık profesyoneli tarafından yönlendirildiğini belirtmemiştir (Mor, İpekoğlu ve Arslanoğlu, 2018). Bu çalışmadaki sporcuların büyük bir çoğunluğu $(\% 86,8)$ besin desteği kullanmadığını belirtmiştir.

Antrenman ve maç dönemlerinde yetersiz enerji alımının, sporcuların performanslarında ve fiziksel gelişiminde olumsuz etkileri görülebilir (Briggs ve arkadaşları, 2015). Bu çalışmaya katılan sporcuların yetersiz enerji aldıkları ve günlük gereksinmenin \%61,36'sını karşıladıkları belirlenmiştir. $\mathrm{Bu}$ durum bütün yaş grubu sporcularında riskli olmasına rağmen, bu yaş grubunda büyüme ve gelişmeyi de etkileyebileceği için daha büyük bir risk oluşturmaktadır. Çalışmamızda, aynı zamanda enerjinin günlük ortalama \%44,5'inin karbonhidrattan, 
\%16,2'sinin proteinden ve \%39,3'ünün yağdan sağlandığı bulunmuştur. Bu adölesanlar protein ve yağdan zengin kaynaklara beslenmelerinde daha fazla yer vermektedir. Sağlıklı beslenme için enerjinin sağlandığı makro besin öğelerinin dağılımı da önem oluşturmaktadır.

Vitaminlerin vücudumuzdaki görevlerinden biri de enerji metabolizmasını düzenlemektir. Choi K., Baek ve Choi W. (2013) tarafindan yapılan çalışmada, sporcuların tiamin tüketimi, önerilen miktarın \%73'ünü karşılamaktadır. Bunun da sporcuların performanslarında düşüşe ve çabuk yorulmalarına sebep olabileceği düşünülmektedir. Bu çalışmada niasin tüketimi önerilen miktarın altında kalırken, Onbaşı (2017) tarafından adölesan sporcularda yapılan çalışmada bütün vitaminlerin önerilen miktarda ya da daha yüksek miktarlarda, A vitaminin her iki çalışmada da önerilen miktarın oldukça üzerinde tüketildiği görülmüştür. Bunun nedeni A vitaminin de zengin kaynağı olan proteinden zengin besinlerin, bu grup tarafindan fazla tüketilmesi olabilir.

Çalışmamızda, çocuk ve adölesan sporcularda yapılan diğer çalışmalar ile benzer olarak çinko, kalsiyum, potasyum minerallerinin önerilen miktardan az tüketildiği görülürken, diğer çalışmaların aksine demir tüketimi öneriler ile örtüşmektedir (Akıcı, Yağmur, Parlak ve Kurdak, 2011, Julián-Almárcegui ve arkadaşları, 2013, Noda ve arkadaşları, 2009, Karabudak, Köksal, Ertaş ve Küçükerdönmez, 2016). Bunun nedeni çalışmamıza katılan bireylerin, demirin de temel kaynağı olan proteinden zengin besinleri tüketmeye özen göstermesi olabilir. Adölesan sporcularda kas fizyolojisinde de önemli bir role sahip olan kalsiyumdan zengin yiyeceklerin az tüketilmesinin, düşük kemik mineral yoğunluğu için bir risk faktörü olduğu bilinmektedir. Özellikle bu çalışmada, düşük enerji alımı ile birlikte bu risk artmaktadır (Barrack, Fredericson, Tenforde ve Nattiv, 2016, Hosseinzadeh ve arkadaşları, 2019).

Çalışmamıza katılan sporcuların sodyum ve fosfor minerallerini önerilen miktarın iki katının üstünde tükettiği görülmüştür. Zhu ve arkadaşları (2013) ve Yang Q. ve arkadaşları (2012) tarafindan yapılan araştırmalarda da adölesanlarda bu oranın sodyum minerali için benzer olduğu, yüksek sodyum tüketiminin yüksek kan basıncı ve enerji tüketiminden bağımsız olarak şişmanlık ve inflamasyon ile ilişkili olduğu tespit edilmiştir (Hew-Buttler, Loi, Pani ve Rosner, 2017).

Sonuç olarak, bu çalışmaya katılan adölesan sporcuların kahvaltı ve öğün düzeni konusunda sorunlarının olduğu belirlenmiştir. Sporcuların en sık belirttiği öğün atlama nedenlerinden biri olan zaman sıkıntısı için uygun antrenman programları geliştirilmeli ve takip edilmelidir. İştahsızlık konusunda bireysel besin tercihlerine yönelik farklı tarifler geliştirilmesi faydalı olabilir. Bunlara paralel olarak bu adölesanların yetersiz enerji aldıkları ve günlük gereksinimlerini karşılayamadıkları bulunmuştur. Öğün atlama ve iştahsızlık sorunlarının giderilmesi gerekliliğinin yanı sıra, bu sporculara ve ailelerine sosyoekonomik düzeylerine göre yeterli ve dengeli bir beslenme planı ile gereksinimlerini karşılamanın önemi iyi anlatılmalıdır.

$\mathrm{Bu}$ yaş grubundaki sporcular, aktif olmayan yaşıtları için yapılan protein tüketimi önerisinin üzerinde protein tüketmelidir. $\mathrm{Bu}$ çalışmada da adölesan sporcuların protein ağırlıklı beslendikleri saptanmıştır. Fakat aşırı protein tüketiminin sağlık üzerine olumsuz etkileri de göz önünde bulundurulmalıdır. Ayrıca geliştirilecek bireysel beslenme planları ile yetersiz aldıkları belirlenen kalsiyum, çinko, potasyum gereksinimleri karşılanmalı; buna karşılık fazla tükettikleri belirlenen sodyum mineralinin kaynakları ve ilerleyen dönemde sağlıkları üzerine olumsuz etkileri öğretilmelidir. Çalışmamızda sporcuların günlük tüketimlerini belirlemek amacıyla retrospektif olarak kullandığımız "Besin Tüketim Formu'nun” prospektif olarak 
birden fazla günü içerecek şekilde doldurulması, sporcuların yiyecek tüketimleri hakkında daha doğru bilgilerin elde edilmesini sağlayacaktır.

Tüm bu nedenlerle, ailelerin ve antrenörlerin adölesan sporcuların beslenmesi konusunda bilinçli ve dikkatli olmaları gerekir. Sporcuların sağlığı ve performansları için beslenme durumları sürekli takip edilmeli, ihtiyaç durumunda diyetisyenler tarafından sağlıklı beslenme eğitimleri verilmelidir. Bu dönemde profesyonel olarak spor yapan gençlerin büyüme ve gelişmelerinin duraksamaması için enerji ve besin öğesi gereksinimlerinin karşılanmasının, sağlıklı ve dengeli beslenme alışkanlıkları kazanmalarının hem performanslarını geliştireceği hem de sağlıklı bir yetişkinlik dönemine geçişi destekleyeceği unutulmamalıdır.

\section{TEŞEKKÜR}

$\mathrm{Bu}$ çalışmanın gerçekleştirilmesinde emeği geçen İstanbul Medipol Üniversitesi Sağlık Bilimleri Fakültesi Beslenme ve Diyetetik bölümü öğrencileri Nurdan Eski, Çağatay Kantarc1, Esra Balsak ve Merve Akgül'e teşekkür ederiz.

\section{KAYNAKLAR}

Akıcı, Ş.Y., Yağmur, C., Parlak, E., Kurdak, S.S. (2011). Erkek yıldız basketbol takımı oyuncularının beslenme durumlarının ve alışkanlıklarının değerlendirilmesi. Turkiye Klinikleri Spor Bilimleri, 3(2), 62-69.

Akman, M., Tüzün, S., Ünalan, P. C. (2012). Adolesanlarda sağlıklı beslenme ve fiziksel aktivite durumu. Nobel Medicus Journal, 8(1), 24-29.

Barrack, M. T., Fredericson, M., Tenforde, A. S., Nattiv, A. (2017) Evidence of a cumulative effect for risk factors predicting low bone mass among male adolescent athletes. British Journal of Sports Medicine, 51(3), 200-205.

Briggs, M. A., Cockburn, E., Rumbold, P. L. S., Rae, G., Stevenson, E. J., Russell, M. (2015). Assessment of energy intake and energy expenditure of male adolescent academy-level soccer players during a competitive week. Nutrients, 7(10), 8392-8401.

Choi, S.K., Baek, S.H., Choi, S.W. (2013). The effects of endurance training and thiamine supplementation on anti-fatigue during exercise. Journal of Exercise Nutrition and Biochemistry, 17(4).

Desbrow, B., McCormack, J., Burke, L. M., Cox, G. R., Fallon, K., Hislop, M., Logan R., Marino N., Swayer M.S., Shaw G., Star, A., Vidgen H., Leveritt M. (2014). Sports Dietitians Australia position statement: sports nutrition for the adolescent athlete. International journal of sport nutrition and exercise metabolism, 24(5), 570584.

Demirezen, E., Coşansu, G. (2005). Adölesan çağı öğrencilerde beslenme alışkanlıklarının değerlendirilmesi. Sürekli Tıp Eğitimi Dergisi, 14(8), 174-178.

Dietary reference intakes for energy, carbohydrate, fiber, fat, fatty acids, cholesterol, protein, and amino acids. (2005). Insitute of Medicine of the National Academies. The National Academies Press Washington, DC. (https://www.nap.edu/catalog/10490/dietary-reference-intakes-for-energy-carbohydrate-fiber-fat-fatty-acidscholesterol-protein-and-amino-acids)

Diker G., Müniroğlu S. (2016). 8-14 yaş grubu futbolcuların seçilmiş fiziksel özelliklerinin yaş gruplarına göre incelenmesi. Ankara Üniversitesi Spor Bilimleri Fakültesi, 14(1), 45-52.

Fortes, L.S., Nascimento-Júnior, J.R.A., Mortatti, A.L., Lima-Júnior, D.R.A.A., Ferreira, M. E. C. (2018). Effect of dehydration on passing decision making in soccer athletes. Research Quarterly for Exercise and Sport, 89(3), $332-339$.

Hew-Butler, T., Loi, V., Pani, A., Rosner, M. H. (2017) Exercise-Associated Hyponatremia: 2017 Update. Frontiers in Medicine, 4(3), 1-10. 
Hosseinzadeh, J., Maghsoudi, Z., Abbasi, B., Daneshvar, P., Hojjati, A., Ghiasvand, R. (2017). Evaluation of Dietary Intakes, Body Composition, and Cardiometabolic Parameters in Adolescent Team Sports Elite Athletes: A Cross-sectional Study. Advanced Biomedical Research, 6(1), 107-113.

Julian-Almarcegui, C., Gómez-Cabello, A., González-Agüero, A., Olmedillas, H., Gomez-Bruton, A., MatuteLlorente, A., icente-Rodríguez, G. (2013). The nutritional status in adolescent Spanish cyclists. Nutricion Hospitalaria, 28(4), 1184-1189.

Karabudak, E., Köksal, E., Ertaş, Y., Küçükerdönmez, Ö. (2016). Dietary intake of Turkish gymnast and nongymnast children. Nutrition and Dietetics, 73(2), 184-189.

Karakuş, M. (2014). Sporcularda ergojenik destek. Spor Hekimliği Dergisi, 49(4) 155-167.

MacLaren, D. (2007). Nutrition and Sport. Londra: Churchill Livingstone, 2007. Erişim adresi: https://books.google.com.tr/books?hl=tr\&lr=\&id=v0RadnSEdM4C\&oi=fnd\&pg=PR7\&dq=MacLaren,+D.+(200 7).+Nutrition+and+Sport.\&ots=O8eMc2lziX\&sig=Czj7lxwHaq8aZca9uQ0C1Tr2Ylg\&redir_esc=y\#v=onepage \&q=MacLaren\%2C\%20D.\%20(2007).\%20Nutrition\%20and\%20Sport.\&f=false

Mor, A., İpekoğlu, G., Arslanoğlu, C. (2018) Spor lisesi öğrencilerinin beslenme alışkanlıklarının incelenmesi (Sinop İli Örneği). Gaziantep Üniversitesi Spor Bilimleri Dergisi, 3(3), 67-77.

Nas, A., Hagele, F., Kahlhofer, J., Keller, J., Rising, R., Bosy-Westphal, A. (2017). Impact of breakfast skipping compared with dinner skipping on regulation of energy balance and metabolic risk. The American Journal of Clinical Nutrition, 10(1), 1351-1361.

Noda, Y., Iide, K., Masuda, R., Kishida, R., Nagata, A., Hirakawa, F., Imamura, H. (2009). Nutrient intake and blood iron status of male collegiate soccer players. Asia Pacific Journal of Clinical Nutrition, 18(3), 344-350.

Onbaş1, Z. Ç. (2017). Adölesan voleybol oyuncularının beslenme bilgi düzeyleri, beslenme durumları ile sıvı tüketimlerine beslenme eğitiminin etkisi. Yüksek Lisans Tezi, Başkent Üniversitesi Sağlık Bilimleri Enstitüsü, Ankara.

Özkarabulut, A.H.,Yürek, M. A. (2017). Basketbol kulüplerindeki kız ve erkek öğrencilerin beslenme durumları ve arasındaki farklar. İstanbul Gelişim Üniversitesi Să̆lık Bilimleri Dergisi, 3, 239-259.

Parlak N. (2008). Konya ilinde aktif spor yapan $15-18$ yaş arası sporcuların sıvı alımı ile ilgili bilgi ve alışkanlıklarının araştırılması. Yüksek Lisans Tezi, Selçuk Üniversitesi Sağlık Bilimleri Enstitüsü, Konya.

Rodrigues, P.R.M., Luiz, R.R., Monteiro, L.S., Ferreira, M.G., Gonçalves-Silva, R.M.V., Pereira, R. A. (2017). Adolescents' unhealthy eating habits are associated with meal skipping. Nutrition, 42, 114-120.

Salici, O., Akkaya, B., Ertürk, H., Orhan, H. (2019). Adölesan Dönemi Voleybolcuların Beslenme Alışkanlıklarının Müsabaka Performansına Etkilerinin İncelenmesi: Isparta Örneği. SDÜ Sağllk Bilimleri Dergisi, $10(3), 249-255$.

Smith, J. W., Jeukendrup, A. (2013). Performance nutrition for young athletes. Nutrition and Enhanced Sports Performance, 523-529.

T.C. Sağlık Bakanlığı. (2016). Türkiye Beslenme Rehberi (TÜBER) 2015. Yayın No: 1031. Ankara.

Türkiye'de Okul Çağı (6-10 Yaş Grubu) Çocuklarında Büyümenin İzlenmesi (TOÇBİ) Projesi Araştırma Raporu, Sağlık Bakanlığı, Temel Sağlık Hizmetleri Genel Müdürlüğü, Hacettepe Üniversitesi Sağlık Bilimleri Fakültesi Beslenme ve Diyetetik Bölümü, Milli Eğitim Bakanlığı, Sağlık Bakanlığı Yayın No:834, Ankara, 2011.

Uğraş A., Savaş Ö. (2002) Bilkent Üniversitesi futbol takımının 10 haftalık ön hazırlık sonrasındaki fiziksel ve fizyolojik karakteristikleri. G.Ü. Gazi Eğitim Fakültesi Dergisi, 22(1), 241-252.

Whitehouse, G., Lawlis, T. (2017) Protein supplements and adolescent athletes: A pilot study investigating the risk knowledge, motivations and prevalence of use. Nutrition and Dietetics, 74(5), 509-515. 
World Health Organization. (2011). Information sheet: Global recommendations on physical activity for health 517 years old. Erişim adresi: https://www.who.int/dietphysicalactivity/publications/recommendations5_17years/en

Yang, Q., Zhang, Z., Kuklina, E. V., Fang, J., Ayala, C., Hong, Y., Merritt, R. (2012). Sodium intake and blood pressure among US children and adolescents. Pediatrics, 130(4), 611-619.

Zhu, H., Pollock, N. K., Kotak, I., Gutin, B., Wang, X., Bhagatwala, J., Dong, Y. (2014). Dietary sodium, adiposity, and inflammation in healthy adolescents. Pediatrics, 133(3), 635-642. 